\title{
A jelnyelvi tolmácsolás kutatásának helye a fordítástudományban
}

\author{
Ungár Nóra \\ E-mail:ungarnora@gmail.com
}

\begin{abstract}
Kivonat: A jelnyelvi tolmácsolás és a jelnyelvi tolmácsok ezidáig ritkán kerültek a magyar fordítástudomány és a kutatók látóterébe. A szakirodalmi áttekintés célja, hogy nagy vonalakban felvázolja a jelnyelvi tolmácsolás sajátosságait és áttekintést adjon a jelnyelvi tolmácsolás kutatásának nemzetközi előzményeiről. Az áttekintés bemutatja a jelnyelvi tolmácsolás kutatásának kapcsolatát általában a tolmácsolás kutatás tudományterületével a fordítástudományon belül, kiemelve a jelnyelvi tolmácsolás kutatásában meghatározó müvek közül párat, amelyek szemléltetik a tudományos érdeklődést meghatározó kérdéseket, paradigmákat, a kutatások hátteréül szolgáló tudományterületeket és kutatásmódszertani megközelítéseket. A cikk bemutatja a magyarországi jelnyelvi tolmácsolás kutatásának helyzetét, és felvázolja a jelnyelvi tolmácsok oktatásának fejlesztését támogató lehetséges kutatási irányokat.
\end{abstract}

Kulcsszavak: tolmácsoláskutatás, jelnyelvi tolmácsolás kutatása, jelnyelvi tolmácsok képzése, közösségi tolmácsolás, tolmács szerep

\section{Bevezetö}

Frishberg (1986) jelnyelvi tolmácsolásról szóló kötetében a tolmácsolást úgy definiálta mint ,az egyik nyelven kifejezett üzenet azonnali másik nyelvre váltásának folyamata. A szóban forgó nyelvek lehetnek beszélt vagy jelelt nyelvek, a [tolmácsolás] meghatározó jellemzője az élő és azonnali közvetítés" (1986: 18). Janzen (2005) szerint a jelnyelvi tolmácsolás és a beszélt nyelvi tolmácsolás közötti különbségeket akár minimálisnak is tekinthetnénk, hiszen a tolmácsoláselmélet mindkettőre érvényes, azonban a jelnyelvekkel is dolgozó tolmácsok tevékenységét néhány sajátos tényező befolyásolja, melyeket figyelembe kell venni. Az egyik, hogy a jelnyelvet használó siket és nagyothalló közösség tagjai az élet minden te-

Hivatkozás: Ungár N. 2020. A jelnyelvi tolmácsolás kutatásának helye a fordítástudományban. Fordítástudomány 22. évf. 2. szám. 44-62.

DOI: https://doi.org/10.35924/fordtud.20.2.3. 
rületén érintkeznek a halló közösség tagjaival, így a tolmácsok is szinte minden elképzelhetö kommunikációs helyzetben tolmácsolhatnak. A másik, hogy a jelnyelvi tolmácsolás során nemcsak nyelvet, de modalitást is kell váltaniuk a tolmácsoknak: az auditív és vizuális csatornákat váltogatva kell észlelniük és újraalkotniuk az üzeneteket.

A jelnyelvi tolmácsolás professzionalizálódása és kutatása, részben a fenti különbségek, részben más történeti vagy nyelvpolitikai okok miatt a beszélt nyelvi tolmácsoláshoz képest később kezdődött el, és a kezdetekben más utat járt be.

A fentebb bemutatott kettős megközelítést - amely a jelnyelvi tolmácsolást egyszerüen „csak” tolmácsolásnak tekinti, ugyanakkor kiemeli a jelnyelvi tolmácsolás egyedi sajátosságait - tükrözi a tudományterület enciklopédiája, a Routledge Encyclopedia of Translation Studies második kiadása is (Baker és Saldanha 2009), ahol az általános tolmácsolásra vonatkozó szócikkekben (pl. a szinkrontolmácsolás meghatározásakor) a jelnyelv is szerepel a példák között, de emellett külön szócikként (Leeson 2009) is megjelenik, ahol elsősorban a jelnyelvi tolmácsolás egyedi sajátosságait mutatja be a szócikk szerzője. Ez mindenképpen azt jelzi, hogy a jelnyelvi tolmácsolást kutatók megtalálták a tolmácsoláselmélettel, a tolmácsolástudománnyal közös pontokat, és a jelnyelvi tolmácsolás egyre inkább részévé válik a fordítástudományi diskurzusnak.

A jelnyelvi tolmácsolás szakmává válásának kezdetét nemzetközi szinten az amerikai jelnyelvi tolmácsok szakmai szervezete (Registry of Interpreters for the Deaf, RID) 1964-es megalakulásához kötik. Ez volt az első szakmai szervezet és egyben névjegyzék is, amely hivatalossá tette a jelnyelvi tolmácsok tevékenységét. Jelnyelvi közvetítésre a szakma elismerését megelözően is sor került, a siket és nagyothalló jelnyelvhasználók esetében elsősorban a jelnyelvet ismerő halló családtagok, barátok vagy a siketiskolai tanárok tolmácsoltak önkéntesen (Henger és Kovács 2005; Napier 2011; Ball 2017; Ingram 2017). A jelnyelvi tolmácsok szakmai névjegyzékének létrejötte már rövidtávon is szükségessé tette a szakmai és felhasználói elvárások összegyüjtését és a szakmai képzés szervezését. Ennek megfelelöen a kezdetekben a jelnyelvi tolmácsolással foglalkozó kutatások részben ezt a két gyakorlati területet szolgálták, a tolmácsolási sztenderdek és az etikai kódexek kialakítását, valamint a jelnyelvi tolmácsok képzését.

Jelen tanulmány a jelnyelvi tolmácsolás kutatásának eddigi előzményeit mutatja be. A bevezetőt követő 2 . rész a jelnyelvi tolmácsok munkanyelveit ismerteti, szükséges magyarázatként a jelnyelvi tolmácsolás sajátosságainak megértéséhez. A 3. rész a külföldi kutatásokat írja le történeti perspektívában, áttekintve a tudomány fejlődésének mérföldköveit és feltérképezve a kutatási területeket néhány jelentős mü említésével. Az utolsó, 4. rész a jelnyelvi kutatások magyarországi helyzetébe ad betekintést. A tanulmányt lezáró összefoglaló pedig a lehetséges kutatási irányokat határozza meg. 


\section{A jelnyelvi tolmácsok munkanyelveiről, a jelnyelvekről}

A jelnyelvi tolmácsolás jellemzően a beszélt és a jelelt nyelvek közötti tolmácsolást jelenti, de vonatkozhat egy beszélt nyelv és annak vizualizált változata közötti tolmácsolásra, azaz transzliterációra is. A tolmácsolástól eltérően a transzliteráció (a jelnyelvek esetében) a beszélt nyelvi információ közvetítését jelenti egy mesterségesen kialakított jelelési rendszer - a jellel kísért magyar, jelesített magyar vagy ujjábécé - segítségével, amely követi a beszélt nyelv szerkezetét és morfológiáját (Leeson 2009; Cokely 2005a).

A jelnyelvi tolmácsok „munkanyelvei” tehát lehetnek különböző természetes beszélt és jelnyelvek, illetve ugyanezen nyelvek eltérő kódolása más csatornákon (pl. hangzó szöveg írott formában megjelenítése, hangzó szöveg néma ismétlése jól szájról olvasható artikulációval), vagy mesterségesen kialakított nyelvváltozatok, kódrendszerek (pl. jelelt nyelvek, Braille-írás manuális megjelenítése, taktilis jelnyelv, könnyen érhető fogalmazású szöveg stb.) (Henger és Kovács 2005).

A jelnyelvek önálló szókinccsel és nyelvtannal rendelkezö, természetes nyelvek, melyek a vizuális-manuális csatornát használják a jelentések közvetítésére. A jelentést a kézjelek és a nem-manuális elemek (mimika, testtartás, gesztusok) együttesen fejezik ki (Sandler és Lillo-Martin 2006).

A jelnyelvek esetében a többesszámot az indokolja, hogy az egyes országok siket és nagyothalló közösségei eltérő jelnyelveket használnak, melyek nem kölcsönösen érthetőek a használók számára, annak ellenére, hogy a jelnyelvek között sok a hasonlóság. Így például Magyarországon a magyar jelnyelv (MJNY), Brazíliában a Língua Brasileira de Sinais (Libras), Németországban a Deutsche Gebärdensprache (DGS) a jelnyelvhasználó közösség nyelve. A jelnyelvek kapcsolódnak a helyi beszélt nyelvekhez, pl. Belgiumban létezik külön francia belga jelnyelv (Langue des signes de Belgique francophone, LSFB) és flamand jelnyelv (Vlaamse Gebarentaal, VGT). Ugyanakkor az angol esetében, amely több országnak is az elsődleges nyelve, az egyes siket közösségek önálló jelnyelveket használnak, például az Egyesült Államokban az amerikai jelnyelvet (ASL), az Egyesült Királyságban a brit jelnyelvet (BSL) és Ausztráliában az ausztrál jelnyelvet (Auslan), melyek jelentősen eltérnek egymástól. A nemzeti jelnyelveken belül előfordulnak még helyi, korcsoportok vagy nemek szerinti dialektusok is. Magyarországon például hét regionális jelnyelvi dialektus érvényesül, melyek kialakulása a hét siketek és nagyothallók oktatásával foglalkozó iskolához kötődik (Vándorffyné 2009). Írországban, ahol csak két iskola volt, egy a fiúk és egy a lányok számára, a férfiak és a nők használnak eltérő dialektusokat (Leeson és Saeed 2012).

A jelnyelvi tolmácsolás történhet beszélt nyelv-jelnyelv párok között oda-viszsza irányban, például az adott nemzeti beszélt nyelvröl nemzeti jelnyelvre (magyar-MJNY); vagy egy „harmadik” idegen nyelv és jelnyelv kombinációjában (angol-MJNY, ASL-magyar); vagy akár két jelnyelv között is (MJNY-ASL). Nemzetközi eseményeken (és az utóbbi időben a nemzetközi siket közösségnek szánt médiában) elterjedt a nemzetközi jelkód (International Sign, IS) használata. 
Az IS nem tekinthető önálló jelnyelvnek, inkább egy, a jelnyelvek közös nyelvtani sajátosságaira épülő és a jelnyelvek (elsősorban az ASL) ikonikus, a jelnyelvhasználók számára könnyen értelmezhető jeleit felhasználó köztes kód. A jelnyelvek közötti tolmácsolás a siket tolmácsok szakterülete, akik a nemzetközi jel és más jelnyelvek között tolmácsolnak. A nemzetközi kódot használják olyan esetekben is, amikor egy siket személy olyan jelnyelven beszél és írott nyelven kommunikál csak, amelyen nem tudnak sem beszélt, sem jelnyelvi tolmácsot biztosítani az adott helyzetben (pl. menekültekkel kapcsolatos eljárások során).

A siket tolmácsok (és ritkábban a jelnyelvi tolmácsok is) közvetítenek még „nem nyelvekre" is azokban a tolmácsolási helyzetekben, amikor az egyik (jellemzően siket) fél nem beszél semmilyen nyelven (csak gesztusokkal kommunikál), vagy nincs megfelelő nyelvi kompetenciája egy tényleges jelnyelven. Ilyen esetekben a jelnyelv mellett a vizuális kommunikáció más eszközeivel: pantomim, testbeszéd, gesztusok, képek, rajz stb. is próbálnak közvetíteni (Henger és Kovács 2005).

A bevezetőben említett transzliteráció esetén a jelnyelvi tolmács a beszélt nyelvet jeleníti meg vizuálisan egy köztes nyelvváltozat vagy kódrendszer segítségével. Ez lehet a jellel kísért magyar, a jelesített magyar, az artikuláció vagy az ujjábécé. A jellel kísért magyar nyelv vagy jelesített magyar egy a jelnyelv jelkincsét felhasználó, a magyar nyelv oktatásához kidolgozott jelrendszer, amely szintaktikailag követi a beszélt nyelvi közlések szerkezetét, és a jelnyelv manuális jeleit kiegészíti olyan mesterséges jelekkel, amelyek a magyar nyelv - a jelnyelvben nem létező, vagy más módon kifejezett - nyelvtani elemeit szimbolizálják, pl. a tárgyrag -t jelét vagy a névelöket.

A jelnyelvet használó siketek és nagyothallók kétnyelvüek, mivel ismerik és használják a magyar (hangzó) és a magyar jelnyelvet is, sőt esetükben bimodális kétnyelvüségröl beszélhetünk, mivel a két nyelv eltérő csatornát (auditív-verbális és vizuális-manuális) használ. A jelnyelv és a (jelesített) magyar nyelv a nyelvhasználatban szimultán is megjelenhet kódkeverés révén, és a két nyelv együttes használata kontakt kódok, pidzsin nyelvváltozatok elterjedt használatát is eredményezi. A kódkeverés mértéke az egyéni beszélők stílusa, nyelvi kompetenciája szerint széles spektrumon változhat (Emmorey 2007; Bartha et al. 2016; Romanek 2017).

\section{A jelnyelvi tolmácsolás kutatása}

Az amerikai jelnyelvi tolmácsok szakmai szervezetének (RID) megalakulása elött közel egy évtizeddel jelentek meg az első jelnyelvvel foglalkozó nyelvészeti munkák, Trevoort (1953) szakdolgozata a holland jelnyelvről és Stokoe (1960) nyelvészeti leírása az amerikai jelnyelvről. Az utóbbi nemzetközi szinten is nagy hatást gyakorolt, és a jelnyelvi kutatások, a jelnyelv elismertetésére irányuló törekvések kiindulópontjává vált.

A jelnyelv mint önálló nyelv tudományos elismerése is szerepet játszhatott abban, hogy az Egyesült Államokban több olyan szövetségi törvény is született, 
amely elöírta a jelnyelvi tolmácsok alkalmazását. Elsőnek például 1954 és 74 között a Vocational Rehabilitation Act többszöri kiegészítése tette szükségessé a foglalkozási rehabilitációs szolgáltatások, majd a felsőfokú oktatási intézmények számára, hogy a szolgálatatásokat igénybe vevő siket és nagyothalló személyek számára jelnyelvi tolmácsolást biztosítsanak (Ball 2017). A jelnyelvi tolmácsok munkáját így a kezdetekben elsősorban a fogyatékos személyek jogainak biztosítását, a siket és nagyothalló személyek számára biztosítandó kommunikációs akadálymentesítést elöíró jogszabályok, szociálpolitikai intézkedések határozták meg.

A siketek közösségei az esélyegyenlőség megteremtése mellett a siket gyermekek oktatásának megreformálása, a jelnyelvi, kétnyelvü oktatás bevezetése miatt is küzdöttek a jelnyelv elismertetéséért. Ez a folyamat - a kommunikációs akadálymentesség és az esélyegyenlöség törvényi feltételeinek megteremtése, a jelnyelv elismertetése, és a siketek oktatásának átalakítása - ha nem is egy időben, de a világ számos országában már szintén lezajlott, vagy folyamatban van. Ezek a körülmények szolgálnak magyarázatként arra, hogy a jelnyelvi tolmácsolást miért tekintették világszerte évtizedeken át elsősorban a fogyatékosságügy területén müködő, szociális segítő szakmának, nem pedig nyelvi közvetítő szolgáltatásnak a beszélt nyelvi tolmácsoláshoz hasonlóan.

Amerikában az 1970-es évek közepén a tolmácsok szakmai közössége kezdeményezte azt a paradigmaváltást, amely szerint ,a tolmácsok már nem mint segítők tevékenykednek, hanem a siketségből adódó fogyatékosság helyett a közös nyelv hiányára összpontosítva - amely hiány a halló és a siket személyek számára egyaránt hátrányt jelent -, a kommunikációt lehetővé tévő közvetítőkként" (Ingram 2017: 128, saját fordítás). A jelnyelvi tolmácsolás kutatása csaknem egy évtizeddel a jelnyelvi kutatások után vette kezdetét, közel húsz évvel lemaradva a beszélt nyelvi tolmácsolással kapcsolatos kutatások mögött.

Metzger (2006) 97, az 1974-es kezdetektől 2005-ig elkészült jelnyelvi tolmácsolásról szóló tanulmányt elemzett, és az empirikus kutatások elméleti és módszertani irányait évtizedenként csoportosítva foglalta össze. Roy és Napier (2015) a jelnyelvi tolmácsolás tudományos megközelítéséről szóló szöveggyűjteménye szintén időrendben mutatja be az 1960-tól 1999-ig megjelent meghatározó munkákat, időszakonként bemutatva az érvényesülő paradigmákat. A továbbiakban az egyes időszakokat és kutatásokat a fenti cikk és szöveggyűjtemény alapján mutatom be.

\subsection{A jelnyelvi tolmácsolás kutatásának kezdetei (1960-1970)}

Az első évtizedben a jelnyelvi kutatások hatására megjelent jelnyelvi tolmácsolásról szóló tanulmányok és tankönyvek szinte kizárólag angol nyelven, az Egyesült Államokban jelentek meg. A RID 1965-ben adta ki Interpreting for Deaf People (Quigley 1965) címmel az első kézikönyvét, amely föként a jelnyelvi tolmácsolás szakmai aspektusaival foglalkozott: a tolmácsolással kapcsolatos általános kérdésekkel, terminológiával, etikával, tolmácsolási helyzetek bemutatásával, a tolmácsképzés tantervével, elsősorban a képzők és a tanulók számára szolgálva hasznos 
információkkal. A 70-es évek elején megjelent cikkek gyakori témája volt a jelnyelvi tolmácsok képességeinek és alkalmasságának vizsgálata. Brasel, Montanelli és Quigley (1974) egy négyéves kutatási program során vizsgálta, hogy milyen kognitív, nyelvi és tolmácsolási képességek, attitüd és tapasztalatok különböztetik meg a kompetens tolmácsokat a középszerü tolmácsoktól. Schein (1974) kutatása a jelnyelvi tolmácsok személyisége és tolmácsolási készségei közötti összefüggéseket vizsgálta a tolmácsolások értékelésével és pszichológiai módszerekkel. Kísérlete alapján a sikeres tolmácsok személyiségére jellemző (1) a vágy, hogy a figyelem középpontjában legyenek és a függetlenségre törekvés, (2) általában nem szoronganak, és nem akarnak másokból együttérzést kiváltani, (3) nem merevek és nem félnek hibázni.

A kutatásokat a jelnyelvi tolmácsképzések, tolmácsvizsgák fejlesztésén túl a jelnyelvi tolmácsok névjegyzéke is motiválta, mivel a RID-nek ki kellett dolgoznia a névjegyzékbe kerülés, a jelnyelvi tolmácsok szakmai értékelésének feltételeit (Roy és Napier 2015).

Az 1970-es évek kutatásainak többsége a közösségi tolmácsolást vizsgálta, funkcionalista megközelítésböl, kvantitatív, kísérleteket és kérdőíves kutatást használó módszerekkel. Több kutatás foglalkozott a célnyelv hatékonysága és a befogadó közönség nyelvi igényeinek kontextus szerinti vizsgálatával, a tolmácsolás kognitív folyamataival (Metzger 2006). Babbini (1976) a fáradtság és a tolmácsok hatékonysága közti összefüggést vizsgálta, és megállapította, hogy a tolmácsok 20-30 perces időtartamokban dolgoznak a leghatékonyabban. Ez a kutatási eredmény máig hatással van a tolmácsok munkájának szervezésére.

Ingram 1974-es cikke (A Communication Model of the Interpreting Process) volt valószínűleg az első elméleti elemzés a jelnyelvi tolmácsolás folyamatának változóiról. Ingram Shannon és Weaver (1949) kommunikációs modelljét vette alapul, és cikkével arra szerette volna felhívni a figyelmet, hogy a tolmácsolás folyamatként, tudományos modellek alapján kutatható, szemben az addig általános, elsősorban a jelnyelvi tolmácsok képességeire, alkalmasságára koncentráló kutatásokkal szemben (Roy és Napier 2015).

Miután az 1970-es években érvénybe léptek az Egyesült Államokban az oktatás és foglalkoztatás területén jelnyelvi tolmácsolást biztosító jogszabályok, a foglalkozási rehabilitációs programokban, a szakképzésben és a felsőoktatásban is jelentősen megnőtt a siket tanulók száma és a jelnyelvi tolmácsolás iránti igény. Az Egyesült Államok kormánya ezért külön támogatást nyújtott, hogy tíz, egymással konzorciumba lépő főiskolán indítsanak egyszerre jelnyelvi tolmácsképzési programot. A képzők között folyamatos volt a tapasztalatcsere, és az évtized végén a Gallaudet University konferenciát szervezett a képzésekben részt vevő szakemberek számára, ahol a résztvevők összegyüjtötték a jelnyelvi tolmácsolással kapcsolatos lehetséges kutatási témákat, mint például a bemeneti követelmények, az oktatási módszerek, környezeti tényezők, oktatási tolmácsolás stb. (Yoken 1979).

Szintén 1979-ben egy szakmai találkozón megalakult a Conference of Interpreter Trainers (CIT, https://www.cit-asl.org/new/) szervezete, azzal a céllal, hogy 
bemutassa a jelnyelvi tolmácsok képzésével, az oktatási stratégiákkal kapcsolatos kutatásokat. Ugyanebben az évben meg is tartották első konferenciájukat.

1977-ben David Gerver, aki megalkotta a szinkrontolmácsolás első feldolgozási modelljét (1971), interdiszciplináris szimpóziumot szervezett Velencében a szinkrontolmácsolás kutatásáról, melyre számos tudományterület kutatóit meghívta (Gerver és Sinaiko 1978). A konferencián hét jelnyelvi tolmácsolással kapcsolatos kutatást is bemutattak, kapcsolatot teremtve a beszélt és a jelnyelvi tolmácsolás kutatói között. Ingram (1978) a konferencia kötetében megjelent írásában a jelnyelvi tolmácsolás és a beszélt nyelvi tolmácsolás hasonlóságára és a közös kutatások hasznára hívta fel a figyelmet, valamint a szociolingvisztikai megközelítés mellett a szemiotikai megközelítés alkalmazását javasolta.

Hurwitz (1980) egy további konferencián bemutatott kutatása a jelnyelvi tolmácsok teljesítményét vizsgálta a tolmácsolás irányától függően. Megállapítása szerint a gyakorlott és a kevésbé gyakorlott tolmácsok számára is nehézséget jelent az amerikai jelnyelvi beszéd megértése és angol nyelvre tolmácsolása az angol nyelvröl amerikai jelnyelvre tolmácsoláshoz képest, bár a teljesítményük a megszerzett tapasztalat arányával egyenesen javul. Ez a Hurwitz által felvetett probléma, a „visszafordítás” nehézsége, később is foglalkoztatja még a kutatókat és a jelnyelvi tolmácsok képzőit.

\subsection{Gyakorló tolmácsok mint kutatók (1980-as évek)}

A 80-as években, a jelnyelvek elismertsége és a jelnyelvi kutatások eredményei hatottak a jelnyelvi tolmácsolást kutatókra. A pszichológiai és pszicholingvisztikai kísérleteket és a kognitív feldolgozási modelleken alapuló megközelítést felváltották a leíró, szociolingvisztikai szempontú kutatások. A korábbi témák (a jelnyelvi tolmács hatékonysága és személyiségjegyei, a forrás- és célnyelvi szövegek összehasonlítása, a nyelvérintkezés és az oktatási tolmácsolás) mellett a tolmácsolási folyamat elemeinek megértése és a konferenciatolmácsolás is figyelmet kapott. A kutatások módszertana is változatosabb: megjelentek a kvalitatív és a kevert módszerü, kérdőívekkel és megfigyeléssel adatokat gyüjtő kutatások, és egyre nagyobb az érdeklődés a beszélt nyelvi tolmácsolás kutatóinak munkája és az együttmüködési lehetőségek iránt.

Ebben az évtizedben a jelnyelvi tolmácsok képzése Amerikában egyre több helyen vált egyetemi alapfokú képzéssé, és az Egyesült Államokon kívül Németországban, Hamburgban és az Egyesült Királyságban, Bristolban is alakultak a jelnyelvvel, a jelnyelvi tolmácsolással foglalkozó tanszékek, kutatóközpontok.

Sok gyakorló, a jelnyelvi tolmácsok képzésében is aktív jelnyelvi tolmács keresett magának olyan doktori programot, ahol a jelnyelvi tolmácsolás kutatásával foglalkozhat, így a szociolingvisztika, az alkalmazott nyelvészet, a szociológia vagy a kulturális antropológia módszerei és paradigmái is megjelentek a kutatásokban. Ezeket a kutatókat elsősorban a jelnyelvi tolmácsolás jobb megértése motiválta, hogy ennek révén is hatékonyabb képzők lehessenek. 
Llewellyn-Jones (1981) pszicholingvisztikai kutatásának eredménye egy, a tolmácsok munkamemóriáját és a szinkrontolmácsolást leíró modell. Cokely (1982) szintén a tolmácsolás pszicholingvisztikai modelljébool kiindulva vizsgálta a jelnyelvi tolmácsolás során előforduló hibákat.

Winston (1989) nyelvészeti szempontú elemzése a jelnyelvi tolmácsok transzliteráció során produkált célnyelvi szövegeit hasonlította össze a forrásnyelvi ASL szövegekkel, négy tolmácsolási stratégiát vizsgálva. Ez az elemzés igazolta elsőként nyelvészeti módszerekkel a kontakthatások érvényesülését a célnyelvi szövegekben. Davis $(1989,1990)$ szociolingvisztikai szempontú kutatásai a jelnyelvi tolmácsolás kapcsán a nyelvi kontakt jelenséget vizsgálták: a nyelvi interferenciát és transzferenciát a kódváltás, a kódkeverés és a lexikai kölcsönzés elemzésével. A kutatás megállapította, hogy a nyelvi interferencia sokkal ritkábban fordul elö, mint a nyelvi transzferencia. Roy $(1989,1993)$ egy egyetemi tanár és diákja között zajló, tolmácsolt találkozó beszélőváltásait (turn-taking) elemezte, és megállapította, hogy a tolmács nem csak semleges csatornája a kommunikációnak. Aktív résztvevővé kell válnia ahhoz, hogy az tolmácsolási helyzet gördülékeny legyen, és menedzselnie kell a beszélőváltásokat. Roy tanulmánya hívta fel a figyelmet először arra, hogy a közösségi tolmács szerepét másként is lehet értelmezni. Ez volt egyben a jelnyelvi közösségi tolmácsolás kutatásában elöször diskurzusalapú szemléletet alkalmazó kutatás is, amely természetes, személyes tolmácsolási helyzetekben figyelte meg a jelnyelvi tolmácsokat (Metzger 2006).

\subsection{Gyakorlatorientált kutatások (1990-2000)}

A huszadik század utolsó évtizedében a publikált kutatások között megjelenik három, nem az Egyesült Államokhoz és az Egyesült Királysághoz köthető tanulmány is. Grbić $(1994,1997)$ szakdolgozata és cikke az ausztriai jelnyelvi tolmácsok helyzetéről, valamint Kyle és Allsop (1997) kilenc országot vizsgáló, az Európai Unió felkérésére végzett felmérése a jelnyelvi tolmácsok intézményi szintü alkalmazásáról. A megelőző időszak kutatási témái mellett a kutatók foglalkoztak még az egészségügyi és igazságügyi tolmácsolási területekkel, a jelnyelvi tolmácsok munkakörülményeivel és a fizikai foglalkozási ártalmakkal.

A tudományos kapcsolatokban az évtized egyik legfontosabb előrelépését a Kanadában 1995-ben megrendezett The First International Conference on Interpreting in Legal, Health and Social Service Settings (The Critical Link: Interpreters in the Community) címü, közösségi tolmácsolásról szóló konferencia szolgálta (Carr et al. 1997), melyen beszélt és jelnyelvi tolmácsok osztották meg tapasztalataikat és kutatási eredményeiket. Az eseményen a jelnyelvi tolmácsolással foglalkozók végre egyenjogú partnerként vettek részt.

Egyre több tolmácsolással foglalkozó folyóiratban jelentek meg a jelnyelvi tolmácsolásról szóló cikkek. 1996-ban az Interpreting első számában már helyet kapott a jelnyelv (Roy 1996) és 1997-ben a Meta egy jelnyelvi tolmácsolásról szóló számot állított össze. 
Ennek az időszaknak meghatározó munkája volt Cokely 1992-ben megjelent könyve, amely a jelnyelvi tolmácsolás általa kidolgozott szociolingvisztikai modelljét mutatja be. Cokely modellje Gile (1991) erőfeszítés-modelljére is építve a jelnyelvi tolmácsolás során előforduló tolmácsolási hibákat kategorizálja, és ezek kiküszöböléséhez ad stratégiákat. Locker (1990) kutatásában az egyetemi környezetben dolgozó jelnyelvi tolmácsok transzliterációs tolmácsolás során ejtett hibáit és a tolmácsolás hatékonyságát vizsgálta. Az ügyfelek értékelései alapján elemezte, hogy a hibák mennyiben befolyásolták az értést és az ügyfelek általános elégedettségét a transzliterációval. Zimmer (1992) a 2.1. részben Hurovitz kapcsán már bemutatott témát, a jelnyelvröl beszélt nyelvre tolmácsolást vizsgálta meg újból, a tolmácsok által használt regiszter, hangszín és az illokuciós erő közvetítése szempontjából.

A siket közösség és a jelnyelvhasználat kapcsán ebben az időszakban jelenik meg a hozzáférés, illetve akadálymentesítés témaköre. Turner (1995) egy kiterjedt kutatás résztvevőjeként vizsgálta a siket emberek hozzáférését az igazságszolgáltatáson belül. Cikkében azt mutatta be, hogy a jelnyelv hogyan érvényesül a bíróságokon, a tárgyalóteremben, és hogyan közvetít a jelnyelvi tolmács. Megfigyeléseinek eredményeként alkotta meg a jelnyelvi tolmács által közvetített interakciókra a co-construction kifejezést, amely azóta a tolmács részvételének diskurzus szempontú elemzésében mind a beszélt, mind a jelnyelvi tolmácsolás kutatásában alkalmazott terminussá vált.

A 80-as, 90-es évek folyamán ismét előtérbe kerültek a jelnyelvi tolmács szakmaiságával, szerepével, hatáskörével kapcsolatos kérdések. Az első jelnyelvi kutatás megjelenése óta a jelnyelv elismertetésével és a társadalmi változásokkal párhuzamosan teret nyertek a siketek és nagyothallók esélyegyenlőségi törekvései. A jelnyelvi tolmácsolás fizetett szakmává vált, és a jelnyelvi tolmácsok igyekeztek szerepüket a konferenciatolmácsoktól átvett csatorna (conduit) modellhez igazítani. A jelnyelvi tolmácsok azonban a konferenciatolmácsoktól eltérően főleg közösségi tolmácsolási feladatokat látnak el, és nincs lehetőségük arra, hogy a terem hátuljában vagy a fülkében ülve láthatatlanok maradjanak. Az ügyfelek egyénileg és a siket közösség is elvárja, hogy kapcsolatot tartsanak a közösséggel, és vállalják annak értékeit azon túl, hogy nyelvileg megfelelően képzettek, professzionálisak, etikusan járnak el, és szem előtt tartják a siket ügyfelek kommunikációs szükségleteit. A jelnyelvi tolmácsok szerepéről folytatott diskurzusok tették világossá a beszélt nyelvi tolmácsok számára, hogy a jelnyelvi tolmácsok a közösségi tolmácsolás úttörői, hiszen ezek a viták már jóval korábban elkezdődtek, mint hogy a közösségi tolmácsolás mint külön szakmai gyakorlat megjelent a tolmácsolásról szóló szakirodalomban (Pöchhacker 1999).

A közösségi tolmácsok szerepéről szóló eszmecserékben a mai napig négy, Witter-Merithew (1986) által leírt, a tolmács szerepét meghatározó modell jelenik meg a leggyakrabban: a segítő, a csatorna, a kommunikációs facilitátor és a bilingvális-bikulturális közvetítő.

McIntire és Sanderson (1995) a tolmácsszerep változását kontinuumként értékelte a korábban már leírt négy modell sorrendjében, melyet a tolmácsok és a siket 
ügyfelek közötti erőviszonyok változásával magyaráztak. McIntire és Sanderson a korábbi négy modell helyett azt javasolta, hogy a tolmácsok váljanak a siket közösség „szövetségeseivé”. A jelnyelvi tolmácsok szerepe még egy évtizeddel később is folyamatosan vitatott kérdés, a legutóbbi Llewellyn-Jones és Lee (2014) által javasolt „,role-space” modell, egy a helyzetekhez és résztvevőkhöz folyamatosan igazodó fluid szerepként írja le a tolmácsszerepet.

A tolmácsok munkakörülményeivel és a munkaköri ártalmakkal három kutatás is foglalkozott, köztük Feuerstein et al. (1997) kutatásában a tolmácsok váz- és izomrendszeri fizikai terhelését vizsgálta. A kérdőíves kutatás során 1398 tolmácstól gyüjtött adatokat a tolmácsok munkakörülményeiről, munkastílusáról, orvosi ellátásáról, tüneteiről és demográfiai jellemzőiről. A kutatás megállapította, hogy a válaszadók közel háromnegyede tapasztalt már nyaki és kéz- vagy csuklófájdalmat. A National Institute for Occupational Safety and Health (NIOSH, Nemzeti Munka- és Egészségvédelmi Intézet) szempontjai alapján az esetek 10-20\%-a értékelhető ténylegesen munkával kapcsolatos panasznak. A panaszok kialakulására hatással vannak a munkakörülmények, a tolmácsok egyéni döntési szabadsága, fizikai terhelése és a munkavégzés során tapasztalt stressz.

A tolmácsok terheléséhez és a kétnyelvüség témájához is kapcsolódik még Ressler (1999) kutatása, aki a tolmácsteamek müködését és a tolmácsolás folyamatát tanulmányozta olyan esetekben, amikor a team egyik tagja halló a másik pedig siket jelnyelvi tolmács.

\subsection{Kutatások a 2000-es évek után}

Az évezredfordulót követően a kutatások és publikációk száma jelentősen megnőtt, köszönhetően a világszerte több helyen alapított egyetemi kutatóközpontoknak és tanszékeknek, valamint a nemzetközi együttmüködéseknek. A jelnyelvi tolmácsolás európai helyzetéről 2016-ban készült felméréshez (de Wit 2016) 34 európai ország, köztük Grúzia, Oroszország, Örményország, Törökország és Ukrajna is küldött adatokat. A felmérésben szereplö országok mindegyikében van valamilyen szintü jelnyelvi tolmácsképzés, ezek közül 21 egyetemi szintü, BA vagy MA képzés. Az egyetemi tanszékeken a képzés mellett kutatás is folyik, például az Egyesült Királyságban (University of Central Lancashire, University of Woolverhampton, Heriot-Watt University), Finnországban (Diak University of Applied Sciences, Helsinki és Turku), Németországban (University of Hamburg, Humboldt University Berlin), Írországban (Trinity College Dublin) és Hollandiában (University of Applied Sciences - Utrecht). Ezen kívül egyre több fiatal kutató folytat jelnyelvi tolmácsolással kapcsolatos kutatást interdiszciplináris doktori programokban.

A 2000-es években több, a jelnyelvi tolmácsolással és a kutatások bemutatásával foglalkozó szerkesztett kötet (pl. Harrington és Turner 2001; Marschark et al. 2005; Janzen 2005; Roberson és Shaw 2018) és a jelnyelvi tolmácsolással foglalkozó doktori kutatás (pl. Metzger 1999; Roy 2000; Napier 2002; Russel 2002; Nicodemus 2009; Stone 2009) is megjelent. 
A jelnyelvi tolmácsolással foglalkozó szövegalapú és kognitív megközelítésű kutatások között fontos megemlíteni Napier (2002) munkáját, amely a kihagyásokat vizsgálta a tolmácsolt célnyelvi beszédben, meghatározva a tolmácsolásokra jellemző stratégiai kihagyásokat. Russel (2002) a konszekutív és szimultán tolmácsolási mód alkalmazását vizsgálta a jogi eljárásokkal kapcsolatos tolmácsolási helyzetekben. Nicodemus (2009) kutatása a jelnyelvi beszéd egységeit és prozodikus jeleit vizsgálta a jelnyelvről beszélt nyelvre tolmácsolás szempontjából. A jelnyelvi tolmácsolási helyzeteket (oktatási, jogi, egészségügyi, közösségi, foglalkoztatási) vizsgáló kutatások területén új téma a video- és távtolmácsolás (Steinberg 2003).

A jelnyelvi tolmácsok szerepével, értékelésével és etikai kérdésekkel foglalkozó kutatások témái között új elem a felhasználók jelnyelvi tolmácsokról és jelnyelvi tolmácsolásról alkotott véleményének és elképzeléseinek vizsgálata (Forestal 2005; Napier és Baker 2004; Kurz és Langer 2004; Holcomb és Smith 2018) és a tolmácsszereppel kapcsolatos új megközelítések (Tate és Turner 2001; LlewellynJones és Lee 2014). Szintén új kutatási témaként jelent meg a jelnyelvi fordítás (vagyis az írott szövegek jelnyelvre fordítása) technikája és célnyelvi szövegalapú elemzése (Stone 2007; Wurm 2010). Végül fontos még megemlíteni a jelnyelvi tolmácsok képzésével kapcsolatos tanulmányokat (pl. Marschark et al. 2005; Crasborn és Bloem 2009; Leeson et al. 2014; van den Bogaerde 2007), melyek reflektálnak a jelnyelvi tolmácsok gyakorlatára és a kutatások eredményeinek felhasználására.

\section{A jelnyelvi tolmácsolás kutatásának helyzete Magyarországon}

A jelnyelv elismertetése és a jelnyelvi tolmácsolás szakmává válása hasonló utat járt be Magyarországon is, mint az Egyesült Államokban és a világ más pontjain, azonban ez a folyamat sokkal később, a rendszerváltás után kezdődött el.

Magyarországon először a fogyatékos személyek jogairól és esélyegyenlőségük biztosításáról szóló, 1998. évi XXVI. törvény rögzítette, hogy biztosítani kell a kommunikációban akadályozott személyek (és családtagjaik) számára „a közérdekü információkhoz és a fogyatékosokat megillető jogokkal, valamint a részükre nyújtott szolgáltatásokkal kapcsolatos információkhoz való hozzáférés lehetőségét” (6. §. (1) és (2) pontjai), valamint ,,a kommunikációban jelentősen gátolt személy számára a közszolgáltatások igénybevételekor lehetővé kell tenni a kölcsönös tájékozódás felvételeit" (7. §.).

A jelnyelv nyelvként való elismerését és a siket és nagyothalló személyek térítésmentes jelnyelvi tolmácsoláshoz való jogát és annak feltételeit a 2009. évi CXXV. törvény a magyar jelnyelvről és a magyar jelnyelv használatáról deklarálta. Mindkét jogszabálynak meghatározó szerepe volt abban, hogy a jelnyelvi tolmácsolás törvényi keretek között szabályozott és államilag térített szolgáltatási tevékenységgé vált. A felhasználói igények növekedésével a jelnyelvi tolmácsszolgálatok fokozatosan egyre több jelnyelvi tolmácsot foglalkoztatnak. 
Jelnyelvi tolmácsolás a fenti két jogszabály életbe lépése elött is régóta létezett Magyarországon, az első „,hivatalos” jelnyelvi tolmácsot az igazságügyi miniszter nevezte ki rendeletben „süketnéma jelbeszéd tolmácsolás szakra” a budapesti megyei bíróság mellé 1951-ben (Henger és Kovács 2005; Szabó 2013). A szakmává válást, a jelnyelvi tolmácsok képzését elöször a 8/1983. (VI.15.) MM-EüM együttes rendelet megjelenése tette lehetővé, melynek nyomán az 1983/84-es tanévben indítottak elöször hivatalos képesítést adó, 3 féléves, levelező szakmai tanfolyamot a Bárczi Gusztáv Gyógypedagógiai Föiskolán (Henger és Kovács 2005).

1996-tól a jelnyelvi tolmácsok képzése számos átalakításon ment keresztül. 2013-tól 2020-ig a 37/2013. (V. 28.) EMMI-rendelet alapján, az Országos Képzési Jegyzékben szereplő 1000 órás, relé jelnyelvi tolmács és jelnyelvi tolmács képesítést, valamint a ráépülő 200 órás képzéssel szak-jelnyelvitolmács képesítést adó képzéseket szervezhettek a felnőttképző intézmények. Az államilag finanszírozott jelnyelvi tolmácsszolgáltatást a Jelnyelvi Tolmácsok Országos Névjegyzékében szereplő tolmácsok végezhetnek. A névjegyzéket a 370/2017. (XII.8.) Korm. rendelet alapján a Fővárosi Kormányhivatal vezeti, és körülbelül 150 jelnyelvi tolmács szerepel rajta.

A jelnyelvi tolmácsok képzése 2003-ban vált OKJ-s szakmai képzéssé, és az azóta eltelt időben a jelnyelvi tolmácsolás nem jelent meg semmilyen képzési szinten a felsőfokú oktatásban. A jelnyelvi tolmácsok OKJ-s képzéséhez 2003 és 2012 között több projekt keretében készült egy tankönyvsorozat és további kötetek a Fogyatékos Személyek Esélyegyenlőségéért Közalapítvány kiadásában, ezek közül ténylegesen csak hatnak témája a jelnyelvi tolmácsolás. A hat kötetből kettő fordítás: Cokely (1992/2005b) és Mindess (1999/2010) könyveinek magyar nyelvü kiadása.

Magyarul jelnyelvi tolmácsolásról ezidáig négy tankönyv: Henger és Kovács (2005) A jelnyelvi tolmácsolás alapismeretei és Henger és Kollár (2005) A jelnyelvi tolmácsolás etikája, valamint Nyírő és Szabó (2005) A jelnyelvi tolmácsolás elmélete és gyakorlata és Királyhidi Dorottya (2005) Tolmácsolás siketvak személyeknek címü munkái jelentek meg, Quigley 1965-ös könyvéhez hasonló szerepet töltve be, melyet közel két évtizeden át használtak az amerikai jelnyelvi tolmácsok képzésében.

A tankönyveken kívül kis számban jelentek meg kutatások is a jelnyelvi tolmácsolásról: Bokor Julianna, Szabó Mária Helga és Kozma Krisztina munkái. Bokor Julianna (2012) szakdolgozata, A magyarországi siket közösség nyelvhasználata: A jelnyelvi tolmácsok helyzete a jelnyelvi törvény és a tolmácsképzés tükrében és az általa végzett kutatásról szóló publikációja (2013a) a jelnyelvi tolmácsolás jogszabályi körülményeit foglalta össze, és a tolmácsok munkavégzéssel kapcsolatos tapasztalatait és a tolmácsképzés során szerzett felkészültségét értékelte kilenc jelnyelvi tolmáccsal készült mélyinterjú alapján.

A kutatás eredményeiből készült egy további tanulmány (Bokor 2013b), amely a jelnyelvi tolmácsolás nyelvi és nem nyelvi tényezőt írja le. A bemutatott nyelvi tényezők: a nyelvi kódok választása, a cél- és forrásnyelv lexikonjának különbségeiből adódó nehézségek, a terminológia hiányából adódó nehézségekre alkalmazott stratégiák és a korrigálási stratégiák. A tolmácsolás sikerességét befolyásoló 
nem nyelvi tényezők között szó esik a felkészülésről, a munkaszervezés nehézségeiről, az önálló tolmácsolásról, a pszichés terhelésről és a tolmácsszereppel kapcsolatos elvárásokból adódó dilemmákról.

Bokor 2014-es rövid tanulmányában azokkal a jelnyelvi tolmácsokkal foglalkozik, akik siket szülök halló gyermekeiként (angolul Child of Deaf Adults, CODA) választják ezt a pályát. A szakirodalom megállapításait Bokor a kutatása során két CODA tolmáccsal készített interjú részleteivel támasztja alá. Kiemeli, hogy a kutatásban részt vevő tolmácsok közül az anyanyelvi jelnyelvhasználó CODA tolmácsok számára, ellentétben a jelnyelvet második nyelvként elsajátító jelnyelvi tolmácsokkal, egyáltalán nem okoz problémát az ügyfelek által választott nyelvi kód használata és megértése egyik tolmácsolási irányban sem, akár magyar nyelvről magyar jelnyelvre, akár magyar jelnyelvröl magyar nyelvre kell tolmácsolniuk.

Szabó Mária Helga (2013) korábban itt is hivatkozott cikke, a Született (jel) tolmácsok, a nyelvi bróker szerepébe kényszerülő, siket családba született, a jelnyelvet anyanyelvükként elsajátító gyermekek élethelyzetét mutatja be Caroline Link A csenden túl (Jenseits der Stille 1996) címü filmjéből vett példákon keresztül.

Kozma Krisztina (2013) kísérletében egy forrásnyelvi szöveg jelnyelvre tolmácsolt célnyelvi változatának érthetőségét hasonlítja össze időskorú siket jelnyelvhasználók bevonásával. A jelnyelvi tolmács által tolmácsolt célnyelvi szöveget a kutatás során összehasonlította a forrásnyelvi szöveggel és egy siket anyanyelvi beszélö által készített fordítással is. A tolmácsolt szöveg eltéréseit a Cokely (1992) által meghatározott tolmácsolási hibák közül négy: a kihagyás, a hozzáadás, a helyettesítés és az interferencia kategóriái szerint azonosította, majd megvizsgálta, hogy az így azonosított hibák milyen mértékben befolyásolták a megértést. Az elemzés eredményei alapján a szintaktikai jellegű hibák és a lexikai jellegű eltérések problémát okoznak a feldolgozás során. Kozma megállapítása szerint a jelnyelvi tolmácsok jelnyelvi felkészültségét és nyelvi tudatosságát mindenképpen segítené egy, a jelnyelvről készült leíró nyelvtani mü és a jelnyelv nyelvtani elemeinek tudatosítása a jelnyelvi oktatás kezdeteitől.

\section{5. Összefoglalás}

Az elsősorban angol nyelvü, jelnyelvi tolmácsolásról szóló kutatások történeti áttekintése alapján látszik, hogy a jelnyelvi tolmácsolás kutatása a kutatási témák változatosságát és az alkalmazott tolmácsoláselméleti paradigmákat és kutatási módszereket tekintve már lépést tartanak a beszélt nyelvi tolmácsolás kutatásával és a fordítástudománnyal.

Ugyanez sajnos a jelnyelvi tolmácsolás kutatásának magyarországi helyzetéről egyáltalán nem mondható el. A kutatások és tudományos munkák hiánya megmutatkozik a jelnyelvi tolmácsok képzésének kidolgozottságán, az oktatásban felhasználható minimális forrásokban, és a tudományos háttér hiányát végül a képzésből felkészületlenül kikerülő jelnyelvi tolmácsok és a felhasználók sínylik meg. 
Leeson és munkatársai (2014) a jelnyelvi tolmácsolás kutatásának aktuális kérdéseiről szerkesztett kötetük bevezetöjében a jelnyelvi tolmácsok képzése kapcsán hívták fel a figyelmet a képzés és az elvárások közötti ellentmondásokra. Annak ellenére, hogy a legtöbb országban a jelnyelvi tolmácsok képzésének szintje elmarad a beszélt nyelvi tolmácsokétól, elvárják tölük, hogy jelnyelvröl beszélt nyelvre, sőt akár egy harmadik nyelvröl is oda-vissza tolmácsoljanak, sokféle kontextusban, sokféle eltérö igényü ügyfél számára. Legyenek képesek közösségi, közszolgáltatásokhoz kapcsolódó, konferencia-, oktatási, politikai és müvészeti tolmácsolási feladatok ellátásra is.

Ugyanakkor a jelnyelvi tolmácsképzéseket jellemzően nem a kutatások eredményei alakítják, holott egyre inkább elvárás, hogy a felsőfokú képzések tartalmát az elméletre alapozott empirikus kutatások eredményeire építsék. Így a kutatásoktatás-gyakorlat-kutatás folytonosságában az oktatás mindig a szakmai gyakorlat tudományos igényü vizsgálatának eredményei alapján tud minél jobb gyakorlati felkészítést adni a hallgatóknak. A jelnyelvi tolmácsok képzései esetében ez azért sem megoldható, mert egyelöre nagyon kevés a jelnyelvi tolmácsolás empirikus kutatásával foglalkozó szakember.

A szerzők három olyan kutatási irányt határoztak meg, melyek nagyban hozzájárulhatnának a jelnyelvi tolmácsképzések és a szakma fejlődéséhez:

(1) olyan, a tolmácsok számára stratégiákat kínáló kutatási eredmények, melyek közvetlenül beépíthetők az egyetemi szintü képzésekbe ( $\mathrm{pl}$. a jelnyelv struktúrájára vagy a stresszkezelésre vonatkozó kutatások),

(2) a jelnyelvi tolmácsok számára segédeszközök (pl. jelnyelvi szókincsgyüjtemény) fejlesztését támogató kutatások,

(3) a jelnyelvi tolmácsok bizonyos kontextusokban jelentkező funkcionális korlátainak (pl. kognitív, tudásbeli, szociális, kulturális stb.) megértését és a tolmácsok feladatairól meglévő tudás gyarapítását segítő kutatások (Leeson et. al. 2014).

A fenti három kutatási irány közül leginkább a harmadik az, amelynek várható eredményei alkalmasak lehetnek arra, hogy a létező képzések tartalmára reflektáljanak, illetve iránymutatással szolgáljanak akár a szakmai továbbképzések, akár egy magasabb szintű tolmácsképzés tartalmának meghatározására. Ugyanakkor a jelnyelvi tolmácsolással kapcsolatos magyar kutatások minimális száma vagy akut hiánya azt is jelenti, hogy bármilyen, akár a korábbi, külföldi kutatások megismétléseként készülő hazai kutatás előrelépést jelenthet.

\section{Irodalom}

Babbini, B. 1976. The effects of fatigue on the competence of interpreters for the deaf. In: Murphy, H. (ed.) Selected Readings in the Integration of Deaf Students at SCUN. Northridge, CA: California State University.

Baker, M., Saldanha, G. (eds) 2009. Routledge Encyclopedia of Translation Studies. New York: Routledge. https://doi.org/10.4324/9780203872062 
Ball, C. 2017. The History of American Sign Language Interpreting. In: Horváth I., Tryuk, M., Pelea, A. (eds) Interpreting through History. L'interprétation à travers l'histoire. International Review of Studies in Applied Modern Languages Special Issue. ClujNapolca: Department of Applied Modern Languages and the Centre for Language Industries. 115-124.

Bartha Cs., Holecz M., Romanek P. Z. 2016. Bimodális kétnyelvűség, nyelvi szociokulturális változatosság és hozzáférés: A JelEsély modell eredményei és távlatai. In: Bartha Cs. (szerk.) A többnyelvüség dimenziói: Terek, kontextusok, kutatási távlatok. Budapest: Akadémiai Kiadó. 337-370.

Brasel, B. B., Motanelli, D., Quigley, S. P. 1974. The component skills of interpreting as viewed by interpreters. Journal of Rehabilitation of the Deaf Vol. 7. No. 3. 20-27.

Bokor J. 2012. A magyarországi siket közösség nyelvhasználata: A jelnyelvi tolmácsok helyzete a jelnyelvi törvény és a tolmácsképzés tükrében. Szakdolgozat. ELTE BTK.

Bokor J. 2013a. A magyarországi jelnyelvi tolmácsok helyzete a jelnyelvi törvény vonatkozásában. In: Félúton 8. A nyolcadik Félúton konferencia (2012) kiadványa. Internetes publikáció: https:/edit.elte.hu/xmlui/handle/10831/20740 (utolsó elérés dátuma: 2020.10.28.)

Bokor J. 2013b. A jelnyelvi tolmácsolás nyelvi és nem nyelvi szempontjai. Egy empirikus kutatás a magyarországi jelnyelvi tolmácsok körében. In: Váradi T. (szerk.) Alknyelvdok 7. Doktoranduszok tanulmányai az alkalmazott nyelvészet köréböl. Budapest: MTA Nyelvtudományi Intézet. 26-35.

Bokor J. 2014. Siket szülők halló gyermekei mint jelnyelvi tolmácsok. In: Havas F., Horváth K., Kugler N., Vladár Zs. (szerk.) Nyelvben a világ. Tanulmányok Ladányi Mária tiszteletére. Budapest: Tinta Kiadó. 339-345.

Carr, E. S., Roberts, R. P., Dufour, A., Steyn, D. 1997. The Critical Link: Interpreters in the Community. Papers from the 1st international conference on interpreting in legal, health and social service settings, Geneva Park, Canada, 1-4 June 1995. Amsterdam: Benjamins.

Cokely, D. 1982. The interpreted medical interview: it loses something in the translation. The Reflector Vol. 3. 5-10.

Cokely, D. 1992. A Sociolonguistic Model. Sign Language Dissertation Series.

Cokely, D. 2005a. Shifting Positionality: A Critical Examination on the turning Point in the Relationship on Interpreters and the Deaf Community. In: Marschark, M., Peterson, R., Winston, E. A. (eds) Sign Language Interpreting and Interpreter Education. Oxford: Oxford University Press. 3-28. https://doi.org/10.1093/acprof/9780195176940.003.0001

Cokely, D. 2005b. A tolmácsolás szociolingvisztikai modellje. Jelnyelvi Tolmácsképzés sorozat. Budapest: Fogyatékosok Esélye Közalapítvány.

Crasborn, O., Bloem, T. 2009. Linguistic variation as a challenge for sign language interpreters and sign language interpreter education in the Netherlands. In: Napier, J. (ed.) International perspectives on sign language interpreter education. Vol. 4. Washington, DC: Gallaudet University Press. 77-95.

Davis, J. 1989. Distinguishing language contact phenomena in ASL interpretation. In: Lucas, C. (ed.) The Sociolinguistics of the Deaf Community. San Diego, California: Academic Press. 85-102. https://doi.org/10.1016/b978-0-12-458045-9.50010-0

Davis, J. 1990. Linguistic transference and interference: Interpreting between English and ASL. In: Lucas, C. (ed.) Sign Language Research: Theoretical Issues. Washington, DC: Gallaudet University. 308-321. 
de Wit, M. 2016. A Comprehensive Guide to Sign Language Interpreting in Europe, 2016 edition. Edition: Maya de Wit.

Emmorey, K. 2007. The psycholinguistics of signed and spoken languages: how biology affects processing. In: Gaskell, G. (ed.) The Oxford Handbook of Psycholinguistics. Oxford: Oxford University Press. 703-721.

https://doi.org/10.1093/oxfordhb/9780198568971.013.0043

Feuerstein, M., Carosella, A., Brunell, L., Marshall, L., DeCaro, J. 1997. Occupational upper extremity symptoms in sign language interpreters: Prevalence and correlates of pain, function and disability. Journal of Occupational Rehabilitation Vol. 7. No. 4. 187-205. https://doi.org/10.1023/b:joor.0000010855.47587.0a

Forestal, E. 2005. The emerging professionals: deaf interpreters and their views and experiences on training. In: Marschark, M., Peterson R., Winston, E. A. (eds) Sign Language Interpreting and Interpreter Education. Oxford: Oxford University Press. 235-258. https://doi.org/10.1093/acprof/9780195176940.001.0001

Frishberg, N. 1986. Interpreting: An Introduction. Registry of Interpreters for the Deaf Publications.

Gerver, D. 1971. Simultaneous interpretation and human information processing. Ph.D. diss., Oxford University.

Gerver, D., Sinaiko, H. W. (eds) 1978. Language Interpretation and Communication. Vol. 6. New York: Plenum Publishing Corporation. https://doi.org/10.1007/978-1-4615-9077-4

Gile, D. 1991. The Processing Capacity Issue in Conference Interpretation. Babel Vol. 37. No. 1. 15-27. https://doi.org/10.1075/babel.37.1.04gil

Grbić, N. 1994. Das Gebärdensprachdolmetschen als Gegenstand einer angewandten Sprach- und Translationswissenschaft unter besonderer Berücksichtigung der Situation in Österreich. Phd. dissertation, University of Graz.

Grbić, N. 1997. Von Handlangern und Experten. Die soziale Praxis des Gebärdensprachdolmetschens im Wandel. In: Grbić, N., Wolf, M. (eds) Text-Kultur - Kommunikation: Translation als Forschungsaufgabe. Festschrift aus Anlaß des 50jährigen Bestehens des Instituts für Übersetzer-und Dolmetscherausbildung an der Universität Graz. Tübingen: Stauffenburg. 293-305.

Harrington, F., Turner, G. (eds) 2001. Interpreting Interpreting: Studies and Reflections on Sign Language Interpreting. Coleford, UK: McLean.

Henger K., Kollár É. 2005. A jelnyelvi tolmácsolás etikája. Jelnyelvi Tolmácsképzés sorozat. Budapest: Fogyatékosok Esélye Közalapítvány.

Henger K., Kovács Zs. 2005. A jelnyelvi tolmácsolás alapismeretei. Jelnyelvi Tolmácsképzés sorozat. Budapest: Fogyatékosok Esélye Közalapítvány.

Holcomb, T. K., Smith, D. H. 2018. Deaf eyes on interpreting. Washington, DC: Gallaudet University Press.

Hurwitz, A. 1980. Interpreters' effectiveness in reverse interpreting: Pidgin Sign English and American Sign Language. In: Caccamise, F., Stangarone, J., Mitchell-Caccamise, M., Banner, E. (eds) A Century of Deaf Awareness in a Decade of Interpreting Awareness: Proceedings of the 6th National Conference of the Registry of Interpreters for the Deaf. Silver Spring, MD: RID. 157-187.

Ingram, R. M. 1974. A communication model of the interpreting process. Journal of Rehabilitation of the Deaf Vol. 7. No. 3. 3-9.

Ingram, R. M. 1978. Sign language interpretation and general theories on language, interpretation and communication. In: Gerver, D., Sinaiko, H. W. (eds) Language In- 
terpretation and Communication. Vol. 6. New York: Plenum Publishing Corporation. 109-118. https://doi.org/10.1007/978-1-4615-9077-4_11

Ingram, R. M. 2017. The Great Paradigm Shift in Sign Language Interpreting: A memoir. In: Horváth I., Tryuk, M., Pelea, A. (eds) Interpreting through History. L'interprétation à travers l'histoire. International Review of Studies in Applied Modern Languages Special Issue. Cluj-Napoca: Department of Applied Modern Languages and the Centre for Language Industries. 125-131.

Janzen, T. 2005. Introduction. In: Janzen, T. (ed.) Topics in Signed Language Interpreting. Amsterdam/Philadelphia: John Benjamins Publishing. 3-24. https://oi.org/10.1075/ btl.63

Királyhidi D. 2005. Tolmácsolás siketvak személyeknek. Jelnyelvi Tolmácsképzés sorozat. Budapest: Fogyatékosok Esélye Közalapítvány.

Kozma K. 2013. Időskori jelfeldolgozás a tolmácsolás hatékonyságának tükrében. Alkalmazott Nyelvtudomány 13. évf. 1-2. szám. 41-58.

Kurz, K. B., Langer, E. C. 2004. Student perspectives on educational interpreting: twenty deaf and hard of hearing students offer insights and suggestions. In: Winston, E. (ed.) Educational Interpreting: How It Can Succeed. Washington, DC: Gallaudet University Press. 9-47.

Kyle, J., Allsop. L. 1997. Sign in Europe: A study of Deaf people and sign language in the European Union. Bristol: Centre for Deaf Studies. University of Bristol.

Leeson, L. 2009. Signed Language Interpreting. In: Baker, M., Saldanha, G. (eds) Routledge Encyclopedia of Translation Studies. New York: Routledge. 274-279. https:// doi.org/10.4324/9780203872062

Leeson, L., Saeed, J. I. 2012. Irish Sign Language. A Cognitive Linguistic Account. Edinburgh: Edinburgh University Press.

Leeson, L., Vermeerbergen, M., Wurm, S. 2014. "Hey Presto!” Preparation, Practice and Performance in the World of Signed Language Interpreting and Translating. In: Leeson, L., Vermeerbergen, M., Wurm, S. (eds) Signed Language Interpreting. Preparation, Practice and Performance. Manchester/Kinderhook, NY: St. Jerome Publishing. 1-11. https://doi.org/10.4324/9781315760209

Llewellyn-Jones, P. 1981. Target language styles and source language processing in conference sign language interpreting. Paper presented at the 3rd International Symposium on Sign Language Interpreting, Bristol, UK.

Llewellyn-Jones, P., Lee, R. G. 2014. Redefining the role of the community interpreter: The concept of "role-space". Lincoln: SLI Press.

Locker, R. 1990. Lexical Equivalence in Transliterating for Deaf Students in the University Classroom: Two Perspectives. Issues in Applied Linguistics Vol. 1. No. 2. 167-195.

Marschark, M., Peterson, R., Winston, E. A. (eds) 2005. Sign Language Interpreting and Interpreter Education. Oxford: Oxford University Press. https://doi.org/10.1093/acprof/9780195176940.001.0001

McIntire, M., Sanderson G. 1995. Bye-Bye! Bi-Bi! Questions of empowerment and role. In: A Confluence of Diverse Relationships: Proceedings of the 13th National Convention of the Registry of Interpreters for the Deaf, 1993. Silver Spring, MD: RID. 94-118.

Metzger, M. 1999. Sign Language Interpreting: Deconstructing the Myth of Neutrality. Washington, DC: Gallaudet University Press.

Metzger, M. 2006. Salient Studies of Signed Language Interpreting in the Context of Community Interpreting Scholarship. In: Hertog, E., van den Veer, B. (eds) Linguis- 
tica Antverpiensia: Taking stock: Research and methodology in community interpreting Vol. 5. Antwerpen: Hogeschool Antwerpen, Hoger Instituut voor Vertalers en Tolken. 263-291.

Mindess, A. 1999. Reading between the signs: Intercultural communication for sign language interpreters. Yarmouth, Me: Intercultural Press.

Mindess, A. 2010. Olvassunk a jelek között! Interkulturális kommunikáció jelnyelvi tolmácsok számára. Budapest: Fogyatékos Személyek Esélyegyenlöségéért Közalapítvány.

Napier, J. 2002. Sign language interpreting. Linguistic coping strategies. Coleford: Douglas McLean.

Napier, J. 2011. Signed Language Interpreting. In: Malmkjaer, K., Windle, K. (eds) The Oxford Handbook of Translation Studies. New York: Oxford University Press. 353372. https://doi.org/10.1093/oxfordhb/9780199239306.001.0001

Napier, J., Baker, R. 2004. Accessing university education: perceptions, preferences and expectations for interpreting by deaf students. Journal of Deaf Studies and Deaf Education Vol. 9. 228-238. https://doi.org/10.1093/deafed/enh024

Nicodemus, B. 2009. Prosodic Markers and Utterance Boundaries in American Sign Language Interpretation. Washington, DC: Gallaudet University Press.

Nyírő Zs., Szabó M. H. 2005. A jelnyelvi tolmácsolás elmélete és gyakorlata. Jelnyelvi Tolmácsképzés sorozat. Budapest: Fogyatékosok Esélye Közalapítvány.

Quigley, S. P. (ed.) 1965. Interpreting for deaf people: A report of a workshop on Interpreting. Governor BaxterState School for the Deaf, Portland, Maine, July 7-27, 1965. U.S. Dept. of Health, Education, and Welfare, Vocational Rehabilitation Administration: U.S. Govt. Print Off.

Pöchhacker, F. 1999. Getting organized: the evolution of community interpreting. Interpreting Vol. 4. No. 1. 125-140. https://doi.org/10.1075/intp.4.1.11poc

Ressler, C. 1999. Direct interpretation and intermediary interpretation. Journal of Interpretation $71-102$.

Roberson, L., Shaw, S. (eds) 2018. Signed language interpreting in the 21st century: an overview of the profession. Washington, DC:Gallaudet University Press.

Romanek P. Z. 2017. A prelingvális siketek nyelvelsajátítása - kitekintés. Anyanyelv-pedagógia. 10. évf. 2. szám. 5-15. https://doi.org/10.21030/anyp.2017.2.1

Roy, C. 1989. A sociolinguistic analysis of the interpreter's role in the turn exchanges of an interpreted event. Ph.D. diss., Georgetown University.

Roy, C. 1993. The problem with definitions, descriptions and the role metaphors of interpreters. Journal of Interpretation Vol. 6. 127-154.

Roy, C. 1996. An interactional sociolinguistic analysis of turn-taking in an interpreted event. Interpreting Vol. 1. No. 1. 39-67. https://doi.org/10.1075/intp.1.1.04roy

Roy, C. 2000. Interpreting as a discourse process. New York: Oxford University Press.

Roy, C. B., Napier, J. 2015. The Sign Language Interpreting Studies Reader. Amsterdam/ Philadelphia: John Benjamins Publishing Company. https://doi.org/10.1075/btl.117

Russel, D. 2002. Interpreting in Legal Contexts: Consecutive and Simultaneous Interpretation. Burnsville, MD: Linstok Press.

Sandler, W., Lillo-Martin, D. 2006. Sign Language and Linguistic Universals. Cambridge: Cambridge University Press. https://doi.org/10.1017/CBO9781139163910

Schein, J. 1974. Personality characteristics associated with interpreter proficiency. Journal of Rehabilitation of the Deaf Vol. 7. No. 3. 33-44. 
Shannon, C. E., Weaver, W. 1949. A Mathematical Model of Communication. UrbanaChampaign, Illinois: University of Illinois Press.

Steinberg, J. 2003. The use of existing video conferencing technology to deliver video remote interpreting services for Deaf vocational rehabilitation clients. Ph.D. diss., Unversity of Arizona.

Stokoe, W. C. 1960. Sign Language Structure: An Outline of the Visual Communication Systems of the American Deaf. Studies in Linguistics: Occasional Papers, 8. Buffalo, NY: Department of Anthropology and Linguistics, University of Buffalo.

Stone, C. 2007. Deaf Translators/Interpreters rendering processes - the translation of oral languages. The Sign Language Translator and Interpreter Vol. 1. No. 1. St. Jerome Publishing. 53-72.

Stone, C. 2009. Towards a Deaf Translation Norm. Washington, D.C.: Gallaudet University Press.

Szabó M. H. 2013. Született (jel)tolmácsok. Nyelv és tudomány. Internetes publikáció: https://www.nyest.hu/hirek/szuletett-jel-tolmacsok (utolsó elérés dátuma: 2019.07.28.)

Tate, G., Turner, G. 2001. The Code and The Culture: Sign Language Interpreting - In search of the new breed's ethics. In: Harrington, F., Turner, G. (eds) Interpreting Interpreting: Studies and Reflections on Sign Language Interpreting. Coleford, UK: McLean.

Turner, G. H. 1995. The bilingual, bimodal courtroom: A first glance. Journal of Interpretation Vol. 7. No. 1. 3-34.

Trevoort, B. T. 1953. Structurele Analyse Van Visueel Taalgebruik Binnen Een Groep Dove Kinderen. PhD. Diss. University of Amsterdam.

van den Bogaerde, B. 2007. Interpreter training from scratch. In: Wadensjö, C., Dimitrova, B. E., Nilsson, A. (eds) The Critical Link 4: Professionalisation of interpreting in the community. Selected papers from the 4th International Conference on Interpreting in Legal, Health and Social Service Settings, Stockholm, Sweden, 20-23 May 2004. Amsterdam/Philadelphia: John Benjamins. 283-295.

Vándorffyné Lancz E. 2009. A magyar jelnyelv regionális változatainak kvantitatív öszszehasonlitó vizsgálata. Budapest: Fogyatékos Személyek Esélyegyenlőségéért Közalapítvány. Magyar Jelnyelvi Programiroda.

Winston, E. 1989. Transliteration: What's the message? In: Lucas, C. (ed.) The Sociolinguistics of the Deaf Community. Washington, D.C.: Gallaudet University Press. 147-164. https://doi.org/10.1016/b978-0-12-458045-9.50013-6

Witter-Merithew, A. 1986. Claiming our destiny. (In two parts). RID Views. October.12. November 3-4.

Wurm, S. 2010. Translation across modalities: the practice of translating written text into recorded signed language: an ethnographic case study. Heriot-Watt University

Yoken, C. 1979. Interpreter training: The state of the art. Washington DC: National Academy of Gallaudet College.

Zimmer, J. 1992. Appropriateness and naturalness in ASL-English interpreting. In: PlantMoeller, J. (ed.) Expanding Horizons: Proceedings of the Twelfth National Conference of Interpreter Trainers. Silver Spring, MD: RID. 81-92. 